\title{
Zinc Transporter ZIP4
}

National Cancer Institute

\section{Source}

National Cancer Institute. Zinc Transporter ZIP4. NCI Thesaurus. Code C139922.

Zinc transporter ZIP4 (647 aa, $68 \mathrm{kDa}$ ) is encoded by the human SLC39A4 gene. This protein is involved in zinc ion transport. 